\title{
Forum
}

PMLA invites members of the association to submit letters that comment on articles in previous issues or on matters of general scholarly or critical interest. The editor reserves the right to reject or edit Forum contributions and offers the PMLA authors discussed in published letters an opportunity to reply. Submissions of more than one thousand words are not considered. The journal omits titles before persons' names and discourages endnotes and works-cited lists in the Forum. Letters should be e-mailed to pmlaforum@mla.org.

\section{What's Literally in Joyce}

\section{To THE EDITOR:}

In "Literally: How to Speak like an Absolute Knave," Stephen Hequembourg notes that many famous authors have used literally not to mean "actually" but rather to intensify the effect of figurative language (vol. 133, no. 1, Jan. 2018, pp. 56-70). For corroboration, he cites the lexicographer Jesse Sheidlower, who points out that this "misuse" of literally appears in the work of Jane Austen, James Joyce, and F. Scott Fitzgerald ("The Word We Love to Hate: Literally"; Slate, 1 Nov. 2005, www.slate.com/articles/life/the_good_word/2005/11/the_word_we_ love_to_hate.html). Sheidlower wants to release the term literally from the English prescriptivists; Hequembourg wants to examine the metaphoric pattern he terms "perverse literalism," through which authors ask us "what it means to understand everyday figures of speech in a more than metaphoric sense" (58).

But Joyce uses literally for a different purpose. Sheidlower quotes only a snippet from Joyce's Ulysses to make his point. Here's the full sentence: "Wagnerian music, though confessedly grand in its way, was a bit too heavy for Bloom and hard to follow at the first go-off but the music of Mercadante's Huguenots, Meyerbeer's Seven Last Words on the Cross and Mozart's Twelfth Mass he simply revelled in, the Gloria in that being, to his mind, the acme of first class music as such, literally knocking everything else into a cocked hat" (Vintage, 1961, p. 661).

This passage is clearly written in Leopold Bloom's style of speaking. It follows what Hugh Kenner termed "the Uncle Charles Principle," in which the telling of a story related by an omniscient narrator is infected (or inflected) by the character it's following (Joyce's Voices; U of California P, 1978, p. 18). Why Uncle Charles? In Joyce's Portrait of the Artist as a Young Man, the description of this character's daily routine echoes

(C) 2018 DAVID GALEF

PMLA 133.3 (2018), published by the Modern Language Association of America 
his own voice: "Every morning, therefore, uncle Charles repaired to his outhouse but not before he had creased and brushed scrupulously his back hair and brushed and put on his tall hat" (Penguin, 1986, p. 60). One may find fault with the term "repaired" as fussily euphemistic_or recognize that it's the drily droll way Uncle Charles would put it. Similarly, in the passage from Ulysses, we the readers are with Bloom, so we read the passage as he would speak it.

Another well-known example of literally in Joyce comes from the opening of "The Dead," in which "Lily, the caretaker's daughter, was literally run off her feet" (Dubliners, Penguin, 1976, p. 175). This sentence is written the way the untutored Lily would describe the affair-that is, it's mimetically accurate. The next sentence in the story, "Hardly had she brought one gentle- man into the little pantry behind the office on the ground floor and helped him off with his overcoat than the wheezy hall-door bell clanged again and she had to scamper along the bare hallway to let in another guest" (175), shows another kind of mimicry: describing without pause a running series of actions that takes several breaths to read out loud, so that the sentence syntactically enacts Lily's marathon. As Kenner notes of Joyce's method, "Syntax was a function of role: of character" (21).

Hequembourg and Sheidlower are right that literally has come to signify the opposite of its original meaning (despite my ardent marginalia in student essays), but Joyce was always a master at imitation, and that's what he's doing here.

David Galef Montclair State University 